Halaman 45-57

\title{
Pengaruh Pemanfaatan Concept Map dalam Model Konstruktivisme tipe Novick terhadap Miskonsepsi pada Konsep Sistem Pernapasan Manusia
}

\author{
The Influence of Utilization Concept Map in Constructivisme Type Novick Model \\ towards Misconception on The Concept of the Human Respiratory System
}

\author{
Renita Yuliana, Puguh Karyanto, Marjono \\ Pendidikan Biologi FKIP Universitas Sebelas Maret \\ Jl. Ir. Sutami 36 A Surakarta \\ Email: tata_renjuly@ymail.com
}

Diterima 23 Juli 2013, disetujui 9 September 2013

\begin{abstract}
The purpose of this research is to ascertain the influence utilization concept map in constructivisme type Novick model to overcome misconception on the concept of the human respiratory system. The research was quasi experiment research using quantitative approach. The research was designed using post-test only with nonequivalent group design. The sample of this research was established by cluster sampling. The populations of this research were all of $11^{\text {th }}$ degree students of science at SMA Negeri 2 Karanganyar in academic year 2012/2013. The samples of this research were the students of 11 th Imersi I as experiment group and $11^{\text {th }}$ Imersi II as control group. The data was collected using reasoning multiple choice test and observation form. The hypotheses analyzed by t-test. The research concluded that application of utilization concept map in constructivisme type Novick model didn't influence on the efforts to overcome the misconceptions on the concept of the human respiratory system with the misconception degree that revealed unti $3,2 \%$ in the experimental group.
\end{abstract}

Key Words: Concept map, constructivisme type Novick model, misconception, the human respiratory system

\section{Pendahuluan}

Irawan dan Sidauruk mengungkap

kan bahwa kelemahan pada proses pendidikan adalah rendahnya pemahaman siswa terhadap konsep (Kustiyah, 2007). Contoh kasus di SMA Negeri 2 Karanganyar menunjukkan bahwa daya serap/ serapan hasil ujian nasional 3 tahun terakhir, yaitu tahun 2010, 2011,dan 2012 jenjang SMA untuk mata uji biologi, beberapa kompetensi dasar menunjukkan hasil yang rendah. Berdasarkan data Balitbang Kemendikbud materi yang terjadi lemah konsep adalah hukum Hardy Weinberg, evolusi, struktur sel tumbuhan dan hewan, struktur DNA/RNA, daur hidup lumut/paku, katabolisme dan anabolisme, jaringan pada manusia, sistem gerak pada manusia, fungsi organ pada alat indera, sistem pencernaan pada manusia serta gangguannya, sistem pernafasan pada manusia serta gangguannya, biotek nologi, dan objek dan permasalahan biologi. Data lemahnya konsep di sekolah (SMA Negeri 2 Karanganyar) juga terjadi di tingkat kabupaten.

Faktor-faktor yang menyebabkan terjadinya lemah konsep pada siswa yaitu metode pembelajaran yang digunakan 
masih konvensional yaitu dengan ceramah. Penggunaan metode ceramah dapat menyebabkan siswa lebih cepat bosan, mengantuk, lebih pasif, dan melakukan aktifitas lain seperti mencatat (Slameto, 2010: 65). Faktor lain yang menyebabkan lemah konsep adalah pemahaman konsep yang tidak sesuai dengan konsep sebenarnya, informasi yang diterima siswa kurang lengkap, pengalaman siswa, dan minat belajar siswa yang rendah. Faktor ketersediaan sumber belajar seperti buku ataupun referensi lain juga akan mempengaruhi lemah konsep pada siswa karena keterbatasan informasi yang mereka terima. Minat membaca buku siswa yang masih rendah mempengaruhi daya serap siswa terhadap konsep materi yang diajarkan.

Pemahaman konsep yang lemah dapat juga terjadi karena adanya kondisi pembelajaran yang kurang memperhati kan prakonsepsi/ konsepsi awal yang dimiliki siswa. Penyebabnya karena para guru mengajar berdasarkan asumsi bahwa pengetahuan dapat dipindahkan secara utuh dari pikiran guru ke pikiran siswa.

Berdasarkan hasil wawancara terhadap siswa, lemahnya konsep yang terjadi karena pelajaran biologi memiliki cakupan materi yang banyak sehingga siswa dituntut untuk menghafal, sifat pelajaran biologi yang abstrak menyebabkan siswa bingung dalam memahami konsep dalam biologi, selain itu istilah-istilah dalam biologi dalam bahasa asing yang sulit dimengerti siswa. Hasil wawancara terhadap guru didapatkan hasil bahwa materi dalam pelajaran biologi yang banyak tidak diimbangi dengan waktu yang cukup yaitu waktu untuk pembelajaran biologi dapat dikatakan singkat, sehingga tidak semua informasi dapat tersalurkan pada siswanya, selain itu minat belajar siswa yang rendah terhadap pelajaran biologi juga mempengaruhi siswa memahami konsep-konsep pada materi biologi.

Berg berpendapat bahwa konsepsi merupakan tafsiran siswa terhadap suatu konsep ilmu tertentu (Komala, 2008). Tafsiran tentang suatu konsep pada setiap individu akan berbeda dengan individu yang lain. Hal ini disebabkan oleh beberapa faktor, yaitu: pengalaman dan pengetahuan yang dimiliki tiap individu berbeda, struktur pengetahuan yang telah dibentuk akan berbeda pada pemikiran masing-masing individu, perbedaan kemampuan menangkap informasi pada saat belajar dapat menentukan apa yang masuk dalam otak dan bagaimana otak tersebut menafsirkan informasi yang diterima (Diyanti, 2010)

Kaum konstruktivis memandang bahwa mengajar merupakan kegiatan 
untuk siswa mengkonstruk/ membangun pengetahuannya sendiri, bukan sekadar memindahkan pengetahuan guru kepada siswa (Yamin, 2008:3). Kesimpulannya bahwa siswalah yang mengkonstruk/ membangun sendiri pengetahuannya dan menghubungkan antara konsep-konsep yang diterimanya. Suatu konsep mempunyai hubungan dengan konsep yang lain, sehingga pengetahuan awal berperan di dalamnya. Pengetahuan yang diperoleh siswa berasal dari pengalaman karena siswa yang mengkonstruksi sendiri pengetahuannya siswa itu sendiri. Konsepsi awal siswa yang diperoleh dari pengamatannya sendiri dapat menyebab kan pengertian yang berbeda dengan para ahlinya, sehingga menyebabkan terjadi nya miskonsepsi.

Miskonsepsi tersebut merupakan penyebab yang bersifat universal. Miskonsepsi adalah perbedaan pemaha man suatu konsep yang dimiliki oleh seorang siswa dengan ahli sains. Miskonsepsi mempunyai sifat tahan terhadap perubahan sehingga sulit untuk diubah. Miskonsepsi dapat terjadi pada semua tingkatan siswa. Siswa yang sudah pernah mengalami miskonsepsi tidak menutup kemungkinan akan terjadi miskonsepsi yang terulang. Terdapat dua faktor yang dapat menyebabkan miskonsepsi, yaitu faktor internal dan faktor eksternal. Faktor internal berasal dari individu itu sendiri, yaitu prakonsepsi/ konsepsi awal yang diperoleh dari pengalaman masingmasing individu. Faktor eksternal dapat berasal dari metode pembelajaran, sifat materi yang abstrak, dan buku teks.

Berkaitan dengan buku teks dalam pembelajaran biologi di kelas, buku ajar yang digunakan sebagai sumber belajar tidak menutup kemungkinan terdapat miskonsespsi pada siswa. Buku teks biologi SMA terdapat kesalahan sebesar 17\%, miskonsepsi $11 \%$, dan memerlukan konsepsi alternatif sebesar $25 \%$ dari seluruh konsep. Sebagian kecil siswa (25\%) terpengaruh oleh kesalahan dan miskonsepsi yang terdapat di dalam buku teks (Adisendjaja 2007).

Secara umum miskonsepsi yang terjadi pada siswa merupakan prioritas yang harus ditangani. Miskonsepsi yang terjadi pada siswa menyebabkan pemahaman siswa rendah dalam menguasai suatu konsep, sehingga miskonsepsi yang terjadi pada siswa perlu untuk diperbaiki. Terdapat berbagai cara untuk mengatasi miskonsepsi adalah analogi seperti pada penelitian Rismayanti (2012) menyimpulkan bahwa remediasi dengan menggunakan analogi dapat menanggulangi miskonsepsi yang dialami siswa. Selain dengan analogi peta konsep juga dapat meminimalisasi 
terjadinya miskonsepsi. Pendidik dapat melihat pemikiran seorang siswa dalam memahami suatu hal yang sedang dipelajari dengan melihat peta konsep tersebut (Musidah 2011). Cara untuk mengatasi miskonsepsi adalah dengan menggunakan Concept Map/ peta konsep (Dahar, 2011: 111).

\section{Concept Map/ peta konsep} merupakan hubungan antara konsep yang bermakna dalam bentuk proposisi (Yamin, 2008: 144). Kelebihan dari peta konsep adalah untuk mengetahui konsep-konsep yang telah dimiliki siswa, supaya belajar bermakna. Penggunaan strategi peta konsep dalam cooperatif learning dapat meningkatkan kualitas proses pembelajaran, meliputi penurunan tingkat miskonsepsi, meningkatkan peran serta siswa dalam pembelajaran (Susilawati, 2008).

Selain pemanfaatan media seperti peta konsep model belajar yang dapat digunakan untuk mengatasi miskonsepsi adalah penemuan terbimbing/ Guided Inquiri (Syaifudin, 2008), model pembelajaran konstruktivisme melalui metode eksperimen (Syahroni, 2011), Cooperatif learning (Susilawati, 2008), Metode demonstrasi (Kurniadi, 2008), dan model konstruktivisme tipe Novick (Diyanti, 2010).

Model mengajar yang dianggap memenuhi dari kerangka konseptual adalah model pembelajaran yang dikemukakan oleh Novick yang dikenal dengan pembelajaran konstruktivisme tipe Novick. Model ini merupakan model yang berawal pada konsep belajar sebagai perubahan konseptual yang dikembangkan dari pendekatan konstruktivisme. Model ini terdiri dari tiga fase, yaitu; mengungkap konsepsi awal siswa, menciptakan konflik konseptual,dan mengupayakan terjadinya akomodasi. Beberapa penelitian di bidang fisika yang dilakukan oleh Natsir (1997) dan Komala (2008) menunjukkan bahwa pembelajaran konstruktivis tipe Novick dapat meningkatakan kemam puan pemahaman siswa. Diyanti (2010) melakukan penelitian dengan menerapakan pembelajaran konstrukti visme tipe Novick untuk meminimalisasi miskonsepsi siswa pada mata pelajaran fisika didapatkan hasil bahwa penggunaan model pembelajaran konstruktivisme tipe Novick dapat lebih meminimalisasi miskonsepsi siswa. Penelitian tentang model konstruktivisme tipe Novick lebih berkembang dalam pembelajaran fisika, padahal berdasarkan prinsip dasarnya dapat dikembangkan dalam berbagi pembelajaran termasuk biologi.

Salah satu konsep yang memiliki serapan rendah pada 2 tahun terakhir yaitu tahun 2011 dan 2012 adalah konsep 
sistem pernapasan. Pada tahun 2011 serapannya sebesar $37,43 \%$ untuk sekolah dan $47,02 \%$ untuk tingkat kabupaten. Pada tahun 2012 serapannya sebesar $57,47 \%$ untuk sekolah dan $60,27 \%$ untuk tingkat kabupaten. Konsep sistem pernapasan yang menitik beratkan pada proses pernapasan manusia merupakan suatu konsep yang memiliki karakteristik yang abstrak dan terjadi pada tubuh manusia. Siswa diharapkan dapat menjelaskan bagaimana prosesproses yang terjadi dalam sistem pernapasan dalam kegiatan pembelajaran nya. Konsep yang bersifat abstrak ini dapat menyebabkan miskonsepsi pada siswa.

Tujuan dari penelitian ini adalah mengetahui pengaruh pemanfaatan concept map dalam model konstruktivisme tipe Novick untuk mengatasi miskonsepsi pada konsep sistem pernapasan manusia.

\section{Metode Penelitian}

Penelitian dilaksanakan di SMA Negeri 2 Karanganyar pada semester genap tahun pelajaran 2012/2013. Penelitian ini termasuk Quasy experiment dengan desain penelitian Posttest Only with Nonequivalent Group Design.

Populasi dalam penelitian ini adalah seluruh siswa kelas XI IPA SMA Negeri 2 Karanganyar tahun pelajaran
2012/2013. Teknik pengambilan sampel dengan cluster sampling. Sampel yang ditetapkan kelas XI Imersi 1 sebagai kelas/ kelompok eksperimen dan XI Imersi 2 sebagai kelas/ kelompok kontrol.

Variabel bebas dalam penelitian ini adalah model pembelajaran konstruktivisme tipe Novick dipadu Peta konsep. Variabel terikat dalam penelitian ini adalah miskonsepsi pada konsep sistem per-napasan manusia. Teknik pengumpulan data dalam penelitian adalah teknik tes dengan tes pilihan ganda beralasan dan non tes dengan lembar observasi.

Tes uji coba instrumen penelitian dilakukan untuk mengetahui validitas tes kognitif menggunakan product moment dan divalidasi konstruk oleh ahli juga untuk mengetahui reliabilitas soal.

Analisis data penelitian meng gunakan uji $t$ yang sebelumnya diuji normalitasnya dengan uji Kolmogorov Smirnov dan uji homogenitas dengan membandingkan antara varians terbesar dibanding varians terkecil.

\section{Hasil dan Pembahasan}

Hasil analisis pemanfaatan concept map dalam model konstruktivisme tipe Novick untuk mengatasi miskonsepsi pada konsep 
sistem pernapasan manusia disajikan pada Tabel 1 berikut.

Tabel 1. Hasil Uji Pengaruh Model Konstruktivisme Tipe Novick dipadu Concept Map Terhadap Miskonsepsi Siswa pada Konsep Sistem Pernapasan Manusia

\begin{tabular}{lll}
\hline & Eksperimen & Kontrol \\
\cline { 2 - 3 } Rata-rata & 0,8 & 1,52 \\
Variansi & 0,917 & 2,343 \\
$\mathrm{~N}$ & 25 & 25 \\
$\mathrm{Dk}$ & 24 & \\
\hline T hitung & 1,994 & \\
T tabel & 2,064 & \\
Signifikansi & 0,053 & \\
Keputusan Uji & $\mathrm{H}_{0}$ diterima & \\
\hline
\end{tabular}

Tabel 1 menunjukkan bahwa nilai $\mathrm{t}_{\text {hitung }}<\mathrm{t}_{\text {tabel, }}$ yaitu $1,994<2,064$ dan Sig. $>0,05$ yaitu 0,053 sehingga dapat diambil keputusan bahwa $\mathrm{H}_{0}$ diterima, hal ini menunjukkan bahwa tingkat miskonsepsi antara kelas eksperimen dengan kelas kontrol tidak berbeda. Berdasarkan perbedaan rata-rata tersebut dapat diketahui bahwa pemanfaatan concept map dalam model konstruktivisme tipe Novick tidak berpengaruh untuk mengatasi miskonsepsi pada konsep sistem pernapasan manusia.
Hasil analisis statistik menunjukkan bahwa pemanfaatan ncept map dalam model konstruktivisme tipe Novick tidak berpengaruh untuk mengatasi miskonsepsi pada konsep sistem per-napasan manusia. Pernyataaan tersebut didasarkan pada hasil uji hipotesis yang menghasilkan keputusan uji nilai $\mathrm{t}_{\text {hitung }}<\mathrm{t}_{\text {tabel }}$, yaitu $1,994<2,064$ dan Sig. > 0,05 yaitu 0,053, sehingga $\mathrm{H}_{0}$ diterima menunjukkan bahwa tidak ada beda antara rata-rata kelas eksperimen dan kelas kontrol.

Berdasarkan hasil penelitian diketahui bahwa tingkat miskonsepsi lebih tinggi pada kelas kontrol, yaitu pada kelas eksperimen sebesar 3,2\% dan pada kelas kontrol sebesar 6,08\%. Gambar 1 menunjukkan bahwa hampir pada setiap sub konsep sistem pernapasan manusia, siswa mengalami miskonsepsi, terutama pada sub konsep mekanisme pernapasan. Siswa belum dapat membedakan antara pernapasan dada dengan pernapasan perut.

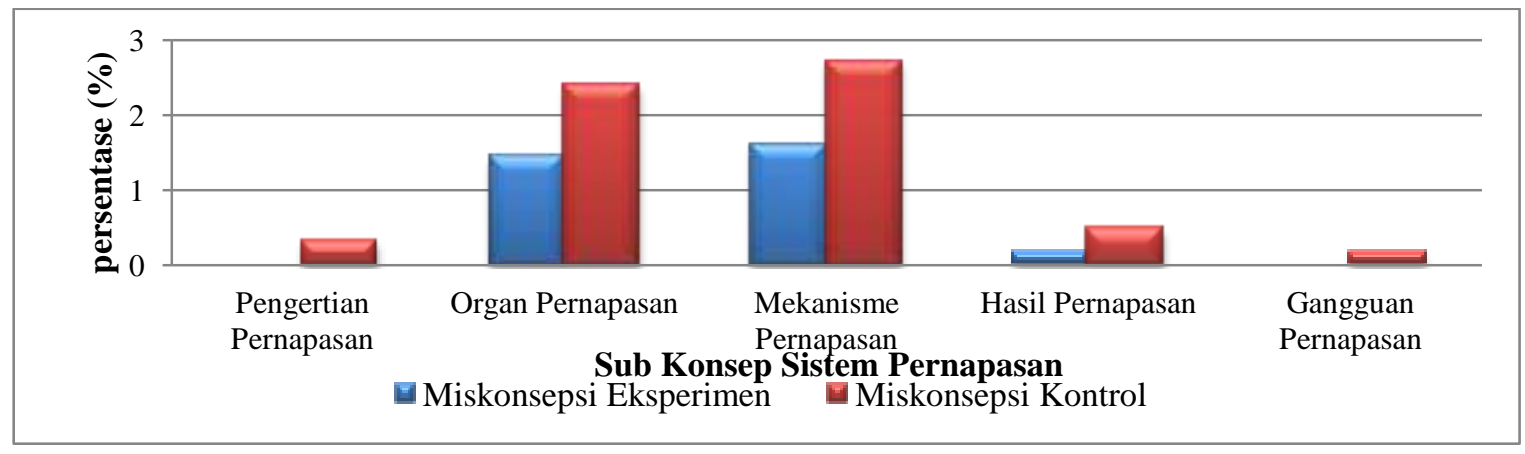

Gambar 1. Persentase Miskonsepsi Pada Setiap Sub Konsep Sistem Pernapasan Manusia 
Model konstruktivisme tipe Novick terdiri dari 3 tahapan, yaitu: fase exposing alternative framework (mengungkap konsepsi awal), fase creating conceptual conflict (men ciptakan konflik konseptual), dan fase encouraging cognitive accomodation (mengupayakan terjadinya akomodasi kognitif). Keterlaksanaan pada masingmasing tahap/ fase dalam model ini dapat dijabarkan sebagai berikut:

Fase exposing alternative framework (mengungkap konsepsi awal)

Pembelajaran pada fase pertama diikuti oleh 26 siswa kelas XI Imersi 1. Fase pertama dalam proses pembelajaran dilakukan dengan menampilkan gambar organ-organ tubuh manusia. Siswa diminta untuk memilih dan mengelom pokkan gambar-gambar yang termasuk dalam organ sistem pernapasan manusia. Suasana pembelajaran di kelas pada fase ini menjadi lebih aktif, siswa termotivasi dalam mengikuti pembelajaran, tetapi tidak semua siswa mau untuk berkontribusi dalam kelompoknya, beberapa diantaranya masih terlihat bingung dalam mengelompokkan gambar tersebut. Hal ini dikarenakan siswa yang terbiasa dengan metode ceramah, sehingga dalam pencarian informasi secara mandiri jarang untuk dilakukan. Siswa yang diharapkan dapat mengkonstruksi pengetahuannya sendiri, cenderung lebih sering bertanya pada guru tentang materi.

Fase pertama dalam model ini dapat diketahui bahwa konsepsi awal siswa mengenai materi pernapasan masih sangat minim. Hal ini dapat terlihat dari jawaban siswa yang disampaikan dalam diskusi kelas dan pada saat pengelompokan gambar sistem organ pernapasan manusia.

Konsepsi awal siswa tentang sub materi struktur dan fungsi organ pernapasan yang sedang dipelajari, hampir sepenuhnya terungkap dalam diskusi kelas. Diskusi dilakukan secara mandiri oleh siswa dalam kelas untuk menjawab fenomena yang terjadi melalui gambar-gambar organ manusia. Pada aspek penerimaaan (akomodasi), akomodasi yang diharapkan adalah siswa dapat memahami bahwa masing-masing organ pernapasan memiliki struktur dan fungsinya masing-masing serta dalam suatu sistem pernapasan, kerja organ tidak berdiri sendiri melainkan saling berhubungan.

Peran guru dalam fase ini adalah sebagai fasilitator, guru belum memberikan komentar atas jawaban siswa dan belum menjawab pertanyaan siswa karena tugas guru dalam pembelajaran adalah mengetahui dengan pasti konsepsi awal siswa secara 
individual terhadap topik yang akan dipelajari. Apabila tidak sesuai dengan konsepsi para ilmuwan, maka guru harus berusaha memodifikasinya menuju konsepsi yang sesuai dengan konsepsi para ilmuwan (Komala, 2008:21). Fase tahap pertama ini merupakan suatu fase untuk mengetahui konsepsi awal siswa tentang materi sisem pernapasan manusia tertutama sub konsep struktur dan fungsi organ pernapasan.

Pelaksanaan pembelajaran pada fase I ini mengalami beberapa hambatan, yaitu alokasi waktu dalam pelaksanaan yang sangat kurang. Fase pertama dalam model ini membutuhkan waktu yang lebih lama karena membutuhkan suatu proses adaptasi pada diri siswa tentang kebiasaan dalam belajar. Siswa yang terbiasa dengan metode ceramah dan tampilan power point cenderung kurang aktif dan kurang terbiasa dalam mencari informasi secara mandiri, sehingga membutuhkan waku yang lebih lama untuk membiasakan siswa mengkonstruk pengetahuannya secara mandiri. Tahapan mengevaluasi konsepsi awal siswa belum terlaksana karena keterbatasan waktu dalam penelitian.

Kesimpulan keterlaksanaan pada tahap/ fase I adalah proses belajar sesuai dengan tahap I model konstruktivisme tipe Novick tetapi belum dapat mengena pada siswa, sehingga pengetahuan yang dikonstruk masih pada tingkatan permukaan dan tahapan hanya terbatas pada keterlaksanaannya.

\section{Fase creating conceptual conflict} (menciptakan konflik konseptual)

Pembelajaran pada fase kedua diikuti oleh 26 siswa kelas XI Imersi 1. Proses pembelajaran pada fase kedua ini adalah dengan simulasi dan percobaan. Proses pembelajaran dengan simulasi dilakukan dengan cara meminta siswa memperagakan mekanisme pernapasan dada dan pernapasn perut. Proses pembelajaran dengan simulasi ini berjalan dengan lancar, siswa lebih aktif, dan mulai belajar mengkonstruksi pengetahuannya berdasarkan apa yang siswa peragakan. Suasana kelas pada saat simulasi menjadi lebih aktif seperti pada tahap I dan siswa lebih terlihat antusias dalam memperagakan simulasi karena siswa menggunakan anggota tubuhnya sendiri dalam proses simulasi tersebut.

Proses pembelajaran selanjutnya adalah dengan percobaan pembuktian kandungan $\mathrm{CO}_{2}$ dan $\mathrm{H}_{2} \mathrm{O}$ dalam udara pernapasan. Percobaan dilakukan menggunakan air kapur dan larutan PP dan BTB untuk membuktikan kandungan $\mathrm{CO}_{2}$, sedangkan untuk membuktikan kandungan $\mathrm{H}_{2} \mathrm{O}$ dengan meniup plastik. Siswa lebih aktif pada proses 
pembelajaran ini, akan tetapi pembelajaran menjadi kurang kondusif akibat siswa lebih banyak becanda dengan plastik yang ditiup kemudian dipecahkan. Percobaan pembuktian kandungan $\mathrm{CO}_{2}$, tidak semua siswa dapat mempraktikkan karena keterbatasan alat. Siswa mulai terbiasa menggunakan model konstruktivisme tipe Novick terlihat dari diskusi siswa dalam pengisian LKS yang mulai dilakukan secara mandiri.

Pelaksanaan pada fase II ini mengalami hambatan seperti keterse diaan alat percobaan yang kurang dan alokasi waktu yang juga kurang. Keterbatasan alat menyebabkan tidak semua siswa dapat mempraktikan percobaan, pengetahuan tentang praktikum diperoleh siswa dari diskusi dalam kelompoknya. Waktu yang kurang menyebabkan siswa kurang leluasa dalam menganalisis hasil percobaannya.

Peran guru dalam fase pembelajaran ini adalah membantu siswa mendeskripsikan dan menjelaskan gagasannya kepada siswa yang lain yang terlibat dalam diskusi, membimbing siswa melakukan demonstrasi atau eksperimen, dan mengarahkan penafsiran siswa terhadap pengamatan yang telah mereka lakukan, salah satunya adalah dengan membimbing terjadinya diskusi kelas (Diyanti, 2010).
Kesimpulan keterlaksanaan pada tahap/ fase II adalah proses belajar sesuai dengan tahap II model konstruktivisme tipe Novick dan siswa lebih menikmati dan antusias pada tahap ke II tersebut, tetapi karena keterbatasan waktu dan alat yang digunakan, konstruksi pengetahuan siswa menjadi kurang optimal.

\section{Fase encouraging cognitive} accomodation (mengupayakan terjadi nya akomodasi kognitif)

Pembelajaran pada fase ketiga diikuti oleh 26 siswa kelas XI Imersi1. Fase ketiga dalam proses pembelajaran dilakukan dengan memberikan pertanyaan kepada siswa yang bersifat menggali seperti bagaimana mekanisme pernapasan dada dan perut, bagaimana proses itu dapat terjadi. Selain itu pertanyaan yang bersifat menggali lainnya adalah dengan bertanya tentang hasil percobaan siswa pada fase kedua.

Suasana pembelajaran cenderung lebih pasif, karena hanya beberapa siswa yang dapat menjawab pertanyaan guru, dan siswa lainnya lebih banyak yang mendengarkan. Fase ketiga ini diharapkan bahwa siswa dapat mengakomodasi materi dalam struktur kognitifnya.

Pelaksanaan pada fase ketiga tidak mengalami hambatan seperti pada fase pertama maupun kedua sehingga 
dapat disimpulkan bahwa pembelajaran pada fase ketiga sesuai dengan tahap model konstruktivisme tipe Novick. Ketiga fase dalam model konstruktivisme berjalan sesuai dengan tahapan. Pada akhir tiap tahapan siswa diminta menghubungkan konsep-konsep yang diterimanya melalui peta konsep. Pembuatan peta konsep seharusnya dilakukan setiap akhir pembelajaran akan tetapi keterlaksanaannya tidak sesuai. Peta konsep dibuat setelah fase kedua karena keterbatasan waktu. Pelurusan peta konsep dilakukan di akhir pertemuan pada fase ketiga berjalan dengan baik.

Berdasarkan data hasil penelitian persentase miskonsepsi pada kelas eksperimen lebih rendah dibanding pada kelas kontrol, yaitu pada kelas eksperimen sebesar 3,2\% dan pada kelas kontrol sebesar 6,08\%. Dilihat dari hasil tingkat pemahaman siswa, pada kelas eksperimen tingkat ketidakpahaman lebih tinggi daripada kelas kontrol. Tingkat pemahaman siswa terhadap soal dapat dilihat pada gambar 2 berikut:

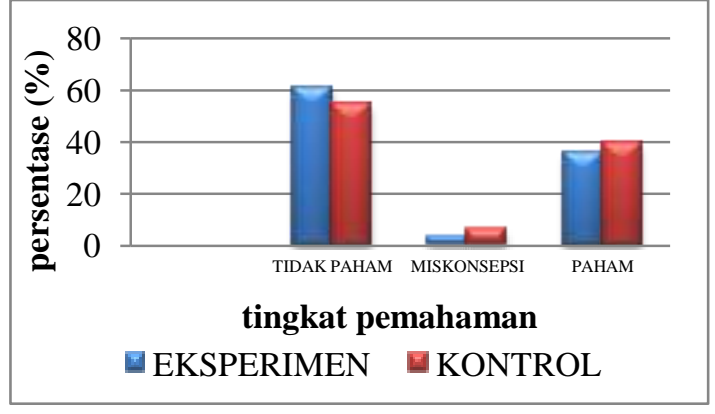

Gambar 2. Grafik Persentase Tingkat pemahaman Siswa

Gambar 2 diatas menunjukkan bahwa tingkat pemahaman siswa pada kelas eksperimen maupun kelas kontrol diatas 50\% tidak paham, yaitu pada kelas eksperimen sebesar 60,2\% dan pada kelas kontrol sebesar 54,72\%. Pada tingkatan paham, kelas kontrol lebih tinggi dibanding dengan kelas ekperimen, yaitu pada kelas kontrol sebesar 39,2\% dan pada kelas eksperimen sebesar 36\%. Tingkat ketidakpahaman pada kelas ekperimen yang lebih tinggi memungkinkan tingkat miskonsepsinya lebih rendah dikarenakan siswa cenderung tidak paham, berbeda dengan kelas kontrol yang tingkat ketidak pahamannya lebih rendah lebih besar kemungkinannya terjadi kesalahan konsep atau miskonsepsi.

Miskonsepsi terjadi pada kelas eksperimen dan kelas kontrol. Miskonspesi terjadi hampir disemua sub konsep sistem pernapasan. Persentase miskonsepsi sub konsep sistem pernapasan manusia pada kelas 
eksperimen maupun kelas kontrol dapat dilihat pada gambar 1. Gambar 1 menunjukkan bahwa miskonsepsi terjadi pada setiap sub konsep pada kelas kelas kontrol, yaitu pada sub konsep pengertian pernapasan, organ pernapasan, meka nisme pernapasan, hasil pernapasan dan gangguan pernapasan, sedangkan pada kelas eksperimen tidak terjadi miskonsepsi pada konsep pengertian pernapasan dan gangguan pernapasan. Persentase miskonsepsi pada masingmasing sub konsep dapat dilihat pada tabel 2 berikut:

Tabel 2. Persentase Miskonsepsi Pada Setiap Sub Konsep Sistem pernapasan Manusia

\begin{tabular}{lll}
\hline \multirow{2}{*}{ Sub Konsep } & Miskonsepsi & \\
\cline { 2 - 3 } & Eksperimen & Kontrol \\
\hline $\begin{array}{l}\text { Pengertian } \\
\text { Pernapasan }\end{array}$ & $0 \%$ & $0,32 \%$ \\
$\begin{array}{l}\text { Organ } \\
\text { Pernapasan }\end{array}$ & $1,44 \%$ & $2,4 \%$ \\
$\begin{array}{l}\text { Mekanisme } \\
\text { Pernapasan }\end{array}$ & $1,6 \%$ & $2,72 \%$ \\
$\begin{array}{l}\text { Hasil } \\
\text { Pernapasan }\end{array}$ & $0,16 \%$ & $0,48 \%$ \\
$\begin{array}{l}\text { Gangguan } \\
\text { Pernapasan }\end{array}$ & $0 \%$ & $0,16 \%$ \\
\hline
\end{tabular}

Miskonsepsi yang paling tinggi adalah pada sub konsep mekanisme pernapasan. Miskonsepsi yang terjadi pada kelas eksperimen seperti pada saat tulang rusuk membesar akan terjadi relaksasi dan pada kelas kontrol miskonsepsi yang terjadi adalah seperti pada saat tekanan udara membesar dan udara masuk ke paru-paru. Kesalahan konsep lain yang dijumpai pada sub konsep mekanisme pernapasan adalah kesamaan antara proses inspirasi dengan pernapasan internal. Miskonsepsi juga ditemukan pada sub konsep organ pernapasan menempati urutan kedua di kelas ekperimen maupun dikelas kontrol. Kesalahan konsep lebih banyak terjadi pada organ alveolus. Beberapa siswa mengalami kesalahan konsep dalam menyebutkan fungsi alveolus seperti pada jawaban siswa berikut: organ tempat terjadinya pertukaran $\mathrm{O}_{2}$ dan $\mathrm{CO}_{2}$ adalah paru-paru. Kesalahan konsep lainnya adalah pada organ tenggorokan, sebagian siswa berpendapat bahwa tenggorokan bukan merupakan organ pernapasan melainkan organ pencernaan, dan organ pernapasan pengganti tenggorokan adalah kerongkongan. Miskonsepsi urutan ketiga pada kelas eksperimen dan kontrol adalah sub konsep hasil pernapasan, pada kelas kontrol persentasenya lebih tinggi dibanding kelas eksperimen. Miskonsepsi yang terjadi seperti udara yang kita hembuskan mengandung karbondioksida sehingga cermin mengembun dan buram. Miskonsepsi urutan keempat pada kelas kontrol adalah pada gangguan pernapasan. Kesalahan konsep pada sub bab gangguan pernapasan seperti penyakit pneumonia tidak disebabkan oleh bakteri. Miskonsepsi pada sub 
konsep pengertian pernapasan terjadi pada kelas kontrol, yaitu pernapasan merupakan penggunaan energi didalam tubuh manusia dalam bentuk panas dan energi kimia melalui prosesn $\mathrm{O}_{2}+$ $\mathrm{C}_{6} \mathrm{H}_{12} \mathrm{O}_{6} \rightarrow \mathrm{CO}_{2}$ dan $\mathrm{H}_{2} \mathrm{O}$.

Hasil data penelitian menunjukkan bahwa pemanfaatan peta konsep dalam model konstruktivisme tipe Novick tidak berpengaruh secara signifikan dalam mengatasi miskonsepsi. Keadaan seperti ini karena siswa yang sudah terbiasa belajar dengan metode ceramah lebih dapat menyesuaikan diri dalam proses belajarnya, sedangkan pada saat siswa menggunakan model pembelajaran baru, siswa harus mulai beradaptasi dalam belajarnya. Penggu naan model pembelajaran konstrukti visme tipe Novick dengan memanfaatkan peta konsep didalamnya membutuhkan waktu secara bertahap. Setiap fase model yang memfasilitasi siswa dalam perubahan konseptual memerlukan tahapan yang tidak bisa dilakukan secara cepat. Siswa yang terbiasa mendengar penyampaian materi melalui ceramah apabila diminta untuk belajar untuk mengkonstruksi pengetahuannya secara mandiri akan lebih kesulitan karena kebiasaan siswa menerima konsep yang sudah terbentuk tanpa mengetahui bagaimana konsep itu dapat terbentuk.

\section{Kesimpulan}

Berdasarkan hasil pembahasan penelitian diperoleh kesimpulan bahwa penerapan concept map dalam model konstruktivisme tipe Novick tidak berpengaruh terhadap upaya mengatasi miskonsepsi pada konsep sistem pernapasan manusia dengan tingkat miskonsepsi yang terungkap 3,2\% pada kelas eksperimen.

\section{Daftar Pustaka}

Adisendjaja, Y. H. \& Romlah, O. (2007). Identifikasi Kesalahan dan Miskonsepsi Buku Teks Biologi SMU. Makalah. Disampaikan pada Seminar Nasional Pendidikan Biologi, Jurusan Pendidikan Biologi FPMIPA Universitas Pendidikan Indonesia 2526 Mei 2007.

Dahar, R. W. (2011). Teori-Teori Belajar dan Pembelajaran. Jakarta: Erlangga.

Diyanti, N. (2010). Penerapan Model Pembelajaran Konstruktivisme Tipe Novick untuk Meminimalisasi Miskonsepsi Siswa pada Mata Pelajaran Fisika. Skripsi Sarjana Tidak Diterbitkan pada FPMIPA UPI Bandung.

Komala, R. (2008). Implementasi Model Pembelajaran Novick Sebagai Upaya untuk Meningkatkan Pemahaman konsep Fisika Siswa SMKN. Skripsi Sarjana Tidak Diterbitkan pada FPMIPA UPI Bandung.

Kurniadi, E. (2011). Mengatasi Miskonsepsi Dinamika dengan Konflik Kognitif Melalui Metode Demonstrasi. Jurnal Pendidikan, 14(1), 2.

Kustiyah. (2007). Miskonsepsi Difusi dan Osmosis pada Siswa MAN Model 
Palangkaraya. Jurnal Ilmiah Guru Kanderang Tingang, 01(1), 1.

Litbang.kemdikbud.go.id

Musidah,U. S. (2011). Identifikasi Miskonsepsi Siswa pada Konsep Ekosistem dengan Menggunakan Peta Konsep. Skripsi Sarjana Tidak Diterbitkan, FPMIPA UPI Bandung.

Natsir, M. (1997). Strategi Penggunaan Model Pembelajaran Novick untuk Meningkatkan Keaktifan dan Pemahaman Siswa tentang Listrik dalam Pembelajaran IPA di Sekolah Dasar. Tesis tidak diterbitkan Pendidikan IPA UPI Bandung.

Rismayanti. (2012). Remediasi Miskonsepsi Siswa SMU pada Konsep Sistem Pernapasan dengan Menggunakan Analogi. Skripsi Sarjana tidak diterbitkan FPMIPA UPI Bandung.

Slameto. (2010). Belajar dan FaktorFaktor yang Mempengaruhinya. Jakarta: Rineka Cipta.

Susilawati, F. D. (2008). Implementasi Strategi Peta Konsep dalam Cooperatif Learning Sebagai Upaya Meminimalisasi Miskonsepsi
Bioteknologi di SMA Negeri 8 Surakarta. Skripsi Sarjana tidak diterbitkan pada FKIP PMIPA UNS Surakarta.

Syahroni, I. (2011). Penggunaan Model Pembelajaran Konstruktivisme Melalui Metode Eksperimen untuk Mengurangi Miskonsepsi Siswa pada Pokok Bahasan Kinematika Gerak Lurus. Skripsi Sarjana tidak diterbitkan FPMIPA UPI Bandung.

Syaifudin, A. (2008). Implementasi Model Pembelajaran Penemuan Terbimbing dalam Matematika Untuk Mengurangi Miskonsespsi Geometri Siswa Kelas VIII SMPN 3 Bulakamba Brebes Jawa Tengah Tahun Ajaran 2007/2008. Skripsi Sarjana tidak diterbitkan Fakultas Sains dan Teknologi UIN Sunan Kalijaga Yogyakarta.

Yamin, M. (2008). Paradigma Pendidikan Konstruktivistik. Jakarta: Gaung Persada Pres. 